Virginia Commonwealth University vCU Scholars Compass

2014

\title{
Unconventional hydrogen bonding to organic ions in the gas phase: Stepwise association of hydrogen cyanide with the pyridine and pyrimidine radical cations and protonated pyridine
}

Ahmed M. Hamid

Virginia Commonwealth University

M. Samy El-Shall

Virginia Commonwealth University, mselshal@vcu.edu

Rifaat Hilal

King Abdulaziz University

Shaaban Elroby

King Abdulaziz University

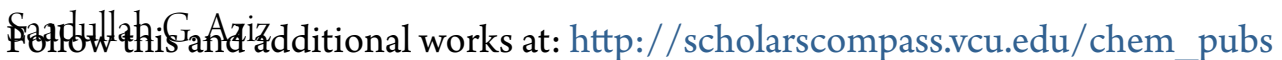
J. g Adulaziz University

Part of the Chemistry Commons

Hamid, A. M., El-Shall, M. S., \& Hilal, R., et al. Unconventional hydrogen bonding to organic ions in the gas phase: Stepwise association of hydrogen cyanide with the pyridine and pyrimidine radical cations and protonated pyridine. The Journal of Chemical Physics, 141, 054305 (2014). Copyright (C) 2014 AIP Publishing LLC.

\section{Downloaded from}

http://scholarscompass.vcu.edu/chem_pubs/66

This Article is brought to you for free and open access by the Dept. of Chemistry at VCU Scholars Compass. It has been accepted for inclusion in Chemistry Publications by an authorized administrator of VCU Scholars Compass. For more information, please contact libcompass@vcu.edu. 


\title{
Unconventional hydrogen bonding to organic ions in the gas phase: Stepwise association of hydrogen cyanide with the pyridine and pyrimidine radical cations and protonated pyridine
}

\author{
Ahmed M. Hamid, ${ }^{1}$ M. Samy El-Shall, ${ }^{1, a)}$ Rifaat Hilal, ${ }^{2}$ Shaaban Elroby, ${ }^{2}$ \\ and Saadullah G. Aziz ${ }^{2}$ \\ ${ }^{1}$ Department of Chemistry, Virginia Commonwealth University, Richmond, Virginia 23284, USA \\ ${ }^{2}$ Department of Chemistry, Faculty of Science, King Abdulaziz University, Jeddah 21589, Saudi Arabia
}

(Received 11 June 2014; accepted 4 July 2014; published online 5 August 2014)

\begin{abstract}
Equilibrium thermochemical measurements using the ion mobility drift cell technique have been utilized to investigate the binding energies and entropy changes for the stepwise association of $\mathrm{HCN}$ molecules with the pyridine and pyrimidine radical cations forming the $\mathrm{C}_{5} \mathrm{H}_{5} \mathrm{~N}^{+} \cdot(\mathrm{HCN})_{\mathrm{n}}$ and $\mathrm{C}_{4} \mathrm{H}_{4} \mathrm{~N}_{2}+\cdot(\mathrm{HCN})_{\mathrm{n}}$ clusters, respectively, with $\mathrm{n}=1-4$. For comparison, the binding of $1-4$ $\mathrm{HCN}$ molecules to the protonated pyridine $\mathrm{C}_{5} \mathrm{H}_{5} \mathrm{NH}^{+}(\mathrm{HCN})_{\mathrm{n}}$ has also been investigated. The binding energies of $\mathrm{HCN}$ to the pyridine and pyrimidine radical cations are nearly equal (11.4 and 12.0 $\mathrm{kcal} / \mathrm{mol}$, respectively) but weaker than the $\mathrm{HCN}$ binding to the protonated pyridine $(14.0 \mathrm{kcal} / \mathrm{mol})$. The pyridine and pyrimidine radical cations form unconventional carbon-based ionic hydrogen bonds with $\mathrm{HCN}\left(\mathrm{CH}^{\delta+} \ldots \mathrm{NCH}\right)$. Protonated pyridine forms a stronger ionic hydrogen bond with $\mathrm{HCN}$ $\left(\mathrm{NH}^{+} \ldots \mathrm{NCH}\right)$ which can be extended to a linear chain with the clustering of additional $\mathrm{HCN}$ molecules $\left(\mathrm{NH}^{+} \ldots \mathrm{NCH} \cdots \mathrm{NCH} \cdots \mathrm{NCH}\right)$ leading to a rapid decrease in the bond strength as the length of the chain increases. The lowest energy structures of the pyridine and pyrimidine radical cation clusters containing 3-4 HCN molecules show a strong tendency for the internal solvation of the radical cation by the $\mathrm{HCN}$ molecules where bifurcated structures involving multiple hydrogen bonding sites with the ring hydrogen atoms are formed. The unconventional H-bonds $\left(\mathrm{CH}^{\delta+} \ldots \mathrm{NCH}\right)$ formed between the pyridine or the pyrimidine radical cations and $\mathrm{HCN}$ molecules $(11-12 \mathrm{kcal} / \mathrm{mol})$ are stronger than the similar $\left(\mathrm{CH}^{\delta+} \ldots \mathrm{NCH}\right)$ bonds formed between the benzene radical cation and $\mathrm{HCN}$ molecules $(9 \mathrm{kcal} / \mathrm{mol})$ indicating that the $\mathrm{CH}^{\delta+}$ centers in the pyridine and pyrimidine radical cations have more effective charges than in the benzene radical cation. (C) 2014 AIP Publishing LLC. [http://dx.doi.org/10.1063/1.4890372]
\end{abstract}

\section{INTRODUCTION}

Hydrogen bonding is one of the most important intermolecular interactions in chemistry and biology both in gas phase and condensed phase systems. ${ }^{1-3}$ A special class of this interaction, usually referred to as ionic hydrogen bonds (IHBs), involves hydrogen bonding between radical ions or protonated molecules and neutral molecules. ${ }^{4}$ IHBs have bond strengths higher than the typical conventional hydrogen bond in neutral systems and they could reach up to 35 $\mathrm{kcal} / \mathrm{mol}$, nearly a third of the strength of covalent bonds. These strong interactions are critical in many fields such as ion induced nucleation, ionic clusters, ion solvation, radiation chemistry, electrochemistry, acid-base chemistry, and selfassembly in supramolecular chemistry. ${ }^{1-6}$ IHBs are also important in biological systems including protein folding, proton transport, membranes, enzyme active centers, and molecular recognition. $^{1-6}$

Unconventional carbon-based IHBs are formed when the hydrogen donors are ionized hydrocarbons containing $\mathrm{CH}$ groups and the hydrogen acceptors are electron lone pairs on hetero atoms such as $\mathrm{O}$ or $\mathrm{N}$, olefin double bonds, or aromatic

\footnotetext{
a) Author to whom correspondence should be addressed. Electronic mail: mselshal@vcu.edu.
}

$\pi$ systems. ${ }^{4}$ For example, carbon-based $\mathrm{CH}^{\delta+} \ldots$ O IHBs appear in the hydration of ionized aromatics such as benzene $\left(\mathrm{C}_{6} \mathrm{H}_{6}{ }^{+} \cdot\right)$, cyclic $\mathrm{C}_{3} \mathrm{H}_{3}{ }^{+}$, and phenyl acetylene $\left(\mathrm{C}_{8} \mathrm{H}_{6}{ }^{+\cdot}\right){ }^{7-10}$ In addition to water, other polar molecules containing lone pair of electrons such as hydrogen cyanide can participate in hydrogen bonding interactions with the ring hydrogen atoms $\left(\mathrm{CH}^{\delta+}\right)$ of ionized aromatics. Hydrogen cyanide is a useful probe of non-covalent interactions because it is a highly polar molecule $(\mu=2.98 \mathrm{D})$, and it can serve both as a hydrogen donor and as a lone-pair hydrogen acceptor in hydrogen bonds. Furthermore, $\mathrm{HCN}$ is an important atmospheric compound known to be produced by biomass burning, and it can be produced in interstellar/nebula environments by the reactions of ammonia and methane. ${ }^{11}$ In fact, HCN polymers have been shown to exist in meteorites, comets, planets, moons, and in circumstellar envelops. ${ }^{12-14}$ Ion-molecule interactions involving $\mathrm{HCN}$, particularly those that lead to the formation of larger species either through chemical addition or association reactions, are of particular interest for the formation of complex organics, clustering, and polymerization in astrochemical environments. ${ }^{15,16}$

We recently studied the stepwise association of $\mathrm{HCN}$ with benzene, substituted benzene, and phenylacetylene radical cations. ${ }^{17-19}$ In benzene ${ }^{+}(\mathrm{HCN})_{\mathrm{n}}$ clusters the lig- 
and molecules are bonded to the benzene hydrogens by $-\mathrm{CH}^{\delta+} \ldots \mathrm{N}$ hydrogen bonds, but linear hydrogen bonded HCN ...HCN ...HCN chains are also formed with further $\mathrm{HCN}$ molecules. ${ }^{17,18}$ In the phenylacetylene ${ }^{+}(\mathrm{HCN})_{n}$ clusters, the dominant interaction was hydrogen bonding between the $\mathrm{C}-\mathrm{H}$ acetylenic hydrogen and the nitrogen atom of the $\mathrm{HCN}$ ligand. ${ }^{19}$ Here also subsequent ligand molecules are added to form linear hydrogen bonded phenylacetylene ${ }^{+}(\mathrm{NCH} \cdot \cdots \mathrm{NCH} \cdot \cdots)$ chains. ${ }^{19}$ Such chains were suggested previously in protonated $(\mathrm{HCN})_{n} \mathrm{H}^{+}$clusters $\left(\mathrm{HCN} \cdots\left(\mathrm{HCN} \cdots \mathrm{H}^{+} \ldots \mathrm{NCH}\right) \cdots \mathrm{NCH}\right)$ where binding enthalpies indicated completion of solvent shells by two (first shell) or four (second shell) $\mathrm{HCN}$ molecules about the proton. $4,15,16$

Ionized aromatics containing $\mathrm{N}$ heteroatoms such as the pyridine and the pyrimidine radical cations can also participate in hydrogen bonding interactions. ${ }^{20,21}$ The hydration of these ions has been investigated both experimentally and theoretically. ${ }^{20,21}$ However, no data exist on the interactions of these ions with $\mathrm{HCN}$ in spite of their importance in biology and origin of life. Here, we present the first study of the stepwise association of $\mathrm{HCN}$ with the pyridine $\left(\mathrm{C}_{5} \mathrm{NH}_{5}+\cdot\right)$ and pyrimidine $\left(\mathrm{C}_{4} \mathrm{~N}_{2} \mathrm{H}_{4}{ }^{+\cdot}\right)$ radical cations and protonated pyridine $\left(\mathrm{C}_{5} \mathrm{NH}_{5}\right) \mathrm{H}^{+}$. We apply equilibrium thermochemical measurements to study the association of 1-4 HCN molecules with the pyridine and pyrimidine radical cations and compare their thermochemistry with the HCN association with the protonated pyridine. We also provide Density Functional Theory (DFT) calculations of the structures of the $\mathrm{C}_{5} \mathrm{NH}_{5}+\cdot(\mathrm{HCN})_{\mathrm{n}}$, $\mathrm{C}_{4} \mathrm{~N}_{2} \mathrm{H}_{4}+\cdot(\mathrm{HCN})_{\mathrm{n}}$, and $\mathrm{C}_{5} \mathrm{NH}_{5} \mathrm{H}^{+}(\mathrm{HCN})_{\mathrm{n}}$ clusters with $\mathrm{n}=1-4$, and investigate the role of hydrogen bonding interactions $-\mathrm{CH}^{\delta+} \ldots \mathrm{NCH}$ and $-\mathrm{NH}^{\delta+} \ldots \mathrm{NCH}$ as compared to the ion-dipole $\mathrm{N}^{\delta+} \ldots \mathrm{NCH}$ interaction in the formation mechanism of these nitrogen-containing cluster ions. The results provide new insights into the factors that determine the structures and energetics of the clusters of polar molecules with $\mathrm{N}$-containing heterocyclic organic ions.

\section{EXPERIMENTAL SECTION}

The gas phase ion association experiments were performed using the Virginia Commonwealth University (VCU) mass-selected ion mobility spectrometer. The details of the instrument can be found in several publications and only a brief description of the experimental procedure is given here. ${ }^{8,17,21}$ In the experiments, the molecular ions of pyridine $\left(\mathrm{C}_{5} \mathrm{H}_{5} \mathrm{~N}^{+\cdot}\right)$, pyrimidine $\left(\mathrm{C}_{4} \mathrm{H}_{4} \mathrm{~N}_{2}{ }^{+} \cdot\right)$ are formed by electron impact ionization using electron energy of 60-70 eV following the supersonic expansion of 40 psi (2.8 bars) of ultra-high pure helium seeded with about $1 \%-4 \%$ of pyridine or pyrimidine vapor through a pulsed supersonic nozzle $(500 \mu \mathrm{m})$ to the vacuum source chamber with $10^{-7}$ mbar pressure. In order to form the $\mathrm{H}^{+}$pyridine $\left(\mathrm{C}_{5} \mathrm{H}_{5} \mathrm{NH}^{+}\right), 10 \% \mathrm{H}_{2}$ in helium was used as carrier gas. $\mathrm{C}_{5} \mathrm{H}_{5} \mathrm{~N}^{+} \cdot \mathrm{C}_{5} \mathrm{H}_{5} \mathrm{NH}^{+}$, or $\mathrm{C}_{4} \mathrm{H}_{4} \mathrm{~N}_{2}{ }^{+} \cdot$ ions were mass-selected by the first quadrupole mass-filter and injected in (30-50 $\mu$ s pulses) into the drift cell which contains neutral HCN gas in a mixture with helium buffer gas. Flow controllers (MKS \# 1479A) are used to maintain a constant pressure inside the drift cell within \pm 1 mTorr. The temper- ature of the drift cell can be controlled to better than $\pm 1 \mathrm{~K}$ using four temperature controllers. Liquid nitrogen flowing through solenoid valves is used to cool down the drift cell. The reaction products can be identified by scanning a second quadrupole mass filter located coaxially after the drift cell. The arrival time distributions (ATDs) are collected by monitoring the intensity of each ion as a function of time. The reaction time can be varied by varying the drift voltage. The injection energies used in the experiments (10-14 eV, laboratory frame) are slightly above the minimum energies required to introduce the ions into the cell against the $\mathrm{HCN} / \mathrm{He}$ outflow from the entrance orifice. Most of the ion thermalization occurs outside the cell entrance by collisions with the $\mathrm{HCN} / \mathrm{He}$ gases escaping from the cell entrance orifice. At a cell pressure of 0.2 Torr, the number of collisions that the ion encounters with the neutral molecules within the $1.5 \mathrm{~ms}$ residence time inside the cell is about $10^{4}$ collisions, which is sufficient to ensure efficient thermalization of the molecular ions.

$\mathrm{HCN}$ is prepared by adding $8 \mathrm{~g}$ of sodium cyanide $(\mathrm{NaCN})$ (Sigma-Aldrich, 97\%) into a $500 \mathrm{ml}$ stainless steel bubbler which is then placed in liquid nitrogen and evacuated followed by the addition of $4 \mathrm{ml}$ of pure sulfuric acid $\left(\mathrm{H}_{2} \mathrm{SO}_{4}\right)$ (Aldrich, 99.999\%) through a stainless steel tube extension of the inlet valve of the bubbler. Following the reaction of sulfuric acid with the sodium cyanide salt inside the bubbler, $\mathrm{HCN}$ gas evolves and the bubbler is allowed to warm up to room temperature. The pressure in the $\mathrm{HCN}$ line is monitored by a Baratron pressure gauge (MKS-626A13TBD).

The equilibrium reactions (taken pyridine radical cation $\mathrm{C}_{5} \mathrm{H}_{5} \mathrm{~N}^{+} \cdot$ as an example) are represented by Eq. (1),

$$
\left[\mathrm{C}_{5} \mathrm{H}_{5} \mathrm{~N}^{+\cdot}(\mathrm{HCN})_{\mathrm{n}-1}\right]+\mathrm{HCN} \rightleftarrows\left[\mathrm{C}_{5} \mathrm{H}_{5} \mathrm{~N}^{+\cdot}(\mathrm{HCN})_{\mathrm{n}}\right]
$$

The establishment of equilibrium is verified when: (1) a constant ratio of the integrated intensity of the product to the reactant ions is maintained over the residence time of the ions at constant pressure and temperature, and (2) the ATDs of the reactant and product ions are identical indicating equal residence times. When the equilibrium conditions are wellestablished, the equilibrium constant, $\mathrm{K}_{\text {eq }}$, can be measured using Eq. (2),

$$
\begin{aligned}
K_{e q} & =\frac{\left[C_{5} H_{5} N^{\cdot+} \cdot(H C N)_{n}\right]}{\left[C_{5} H_{5} N^{\cdot+} \cdot(H C N)_{n-1}\right] \cdot[H C N]} \\
& =\frac{I\left|C_{5} H_{5} N^{\cdot+} \cdot(H C N)_{n}\right|}{I\left[C_{5} H_{5} N^{\cdot+} \cdot(H C N)_{n-1}\right] \cdot P_{H C N}},
\end{aligned}
$$

where $I\left[\mathrm{C}_{5} \mathrm{H}_{5} \mathrm{~N}^{\cdot+} \cdot(\mathrm{HCN})_{n-1}\right]$ and $I\left[\mathrm{C}_{5} \mathrm{H}_{5} \mathrm{~N}^{\cdot+} \cdot(\mathrm{HCN})_{n}\right]$ are the integrated intensities of the ATDs of the reactant and product cluster ions, respectively of reaction (1) and $\mathrm{P}_{H C N}$ is the pressure of $\mathrm{HCN}$ (in atmosphere) inside the drift cell. The equilibrium constant, $\mathrm{K}_{\mathrm{eq}}$, is measured at different temperatures and from a van't-Hoff plot, $\Delta \mathrm{H}^{\circ}$ and $\Delta \mathrm{S}^{\circ}$ values are obtained from the slope and intercept, respectively. The measured values are duplicated at least three times and the average values are reported in Table I the corresponding uncertainties. 
TABLE I. Measured thermochemistry $\left(-\Delta \mathrm{H}^{\circ}{ }_{\mathrm{n}-1, \mathrm{n}}\right.$ and $\left.-\Delta \mathrm{S}^{\circ}{ }_{\mathrm{n}-1, \mathrm{n}}\right)$ of the formation of $\mathrm{C}_{5} \mathrm{H}_{5} \mathrm{~N}^{+} \cdot(\mathrm{HCN})_{\mathrm{n}}$ and $\mathrm{C}_{5} \mathrm{H}_{5} \mathrm{NH}^{+}(\mathrm{HCN})_{\mathrm{n}}$ clusters; with $\mathrm{n}=1$ 4 and the corresponding calculated binding energies for the two lowest energy structures within $2 \mathrm{kcal} / \mathrm{mol}$.

\begin{tabular}{lccc}
\hline \hline \multicolumn{3}{c}{ Pyridine $^{+} \cdot(\mathrm{HCN})_{\mathrm{n}}$} \\
\hline $\mathrm{n}$ & $-\Delta \mathrm{H}^{\text {oa }}$ & $-\Delta \mathrm{S}^{\mathrm{ob}}$ & $\Delta \mathrm{E}(\mathrm{M} 06-2 \mathrm{X})^{\mathrm{c}}$ \\
\hline 1 & 11.4 & 21.8 & $11.9-11.4$ \\
2 & 8.8 & 19.3 & $10.9-9.4$ \\
3 & 7.8 & 20.4 & $10.6-9.6$ \\
4 & 6.4 & 16.5 & $8.7-6.8$ \\
& & Pyridine $^{+}(\mathrm{HCN})_{\mathrm{n}}$ & \\
$\mathrm{n}$ & $-\Delta \mathrm{H}^{\text {oa }}$ & $-\Delta \mathrm{S}^{\text {ob }}$ & $\Delta \mathrm{E}(\mathrm{M} 06-2 \mathrm{X})^{\mathrm{c}}$ \\
\hline 1 & 14.0 & 26.6 & 16.0 \\
2 & 9.7 & 22.9 & $12.0-11.3$ \\
3 & 8.5 & 23.2 & $8.1-7.6$ \\
4 & 6.1 & 14.5 & $8.4-7.0$ \\
\hline \hline
\end{tabular}

${ }^{\mathrm{a}} \Delta \mathrm{H}_{\mathrm{n}-1, \mathrm{n}}^{\circ}$ units are $\mathrm{kcal} / \mathrm{mol}$.

${ }^{\mathrm{b}} \Delta \mathrm{S}_{\mathrm{n}-1, \mathrm{n}}^{\circ}$ units are cal $/ \mathrm{mol} \mathrm{K}$. Error estimate for experimental values from standard deviations of van't Hoff and from usual uncertainties in clustering equilibrium temperature studies: $\Delta \mathrm{H}^{\circ} \pm 1 \mathrm{kcal} / \mathrm{mol}, \Delta \mathrm{S}^{\circ} \pm 2 \mathrm{cal} / \mathrm{mol} \mathrm{K}$.

${ }^{\mathrm{c}}$ Binding energy calculated at the M06-2X/6-311++G(d,p) level with ZPE and BSSE corrections included.

\section{THEORETICAL SECTION}

DFT calculations of the lowest energy structures of $\mathrm{C}_{5} \mathrm{H}_{5} \mathrm{~N}^{+\cdot} \cdot(\mathrm{HCN})_{\mathrm{n}}, \quad \mathrm{C}_{4} \mathrm{H}_{4} \mathrm{~N}_{2}^{+\cdot} \cdot(\mathrm{HCN})_{\mathrm{n}}, \quad$ and $\mathrm{C}_{5} \mathrm{H}_{5} \mathrm{NH}^{+} \cdot(\mathrm{HCN})_{\mathrm{n}}$ clusters with $\mathrm{n}=1-4$ were carried out at the M06-2X/6-311++G(d,p) level using the Gaussian

(a)

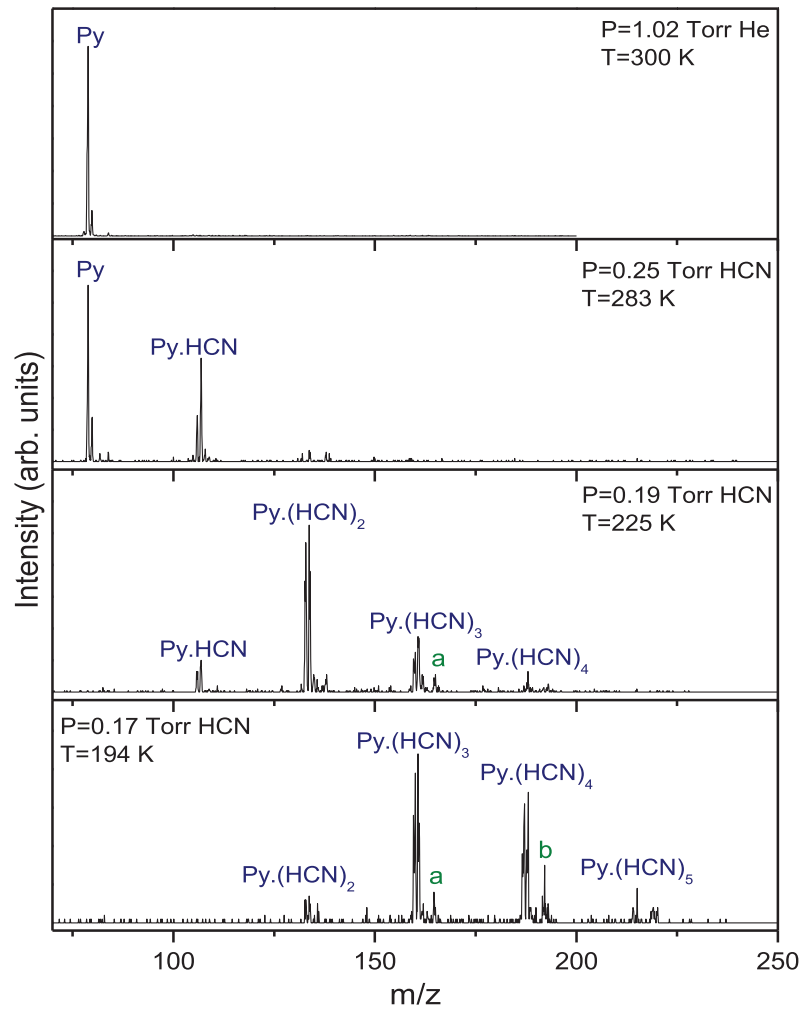

09 suite of programs. ${ }^{22}$ Frequency calculations have been performed for all the optimized geometries at the same level of theory to obtain the zero point vibrational energy (ZPVE) and to verify the absence of any imaginary frequencies. The calculated binding energies (with respect to $\left.\mathrm{C}_{5} \mathrm{H}_{5} \mathrm{~N}^{+\cdot} \cdot(\mathrm{HCN})_{\mathrm{n}-1}+\mathrm{HCN}\right)$ were corrected for basis set superposition error (BSSE) using the scheme of Boys and Bernardi as described in the Gaussian program. ${ }^{22}$

\section{RESULTS AND DISCUSSION}

\section{A. Association of $\mathrm{HCN}$ with the pyridine radical cation and protonated pyridine}

Figure 1(a) displays the mass spectra obtained following the injection of the mass-selected pyridine ion into the drift cell containing 1.0 Torr $\mathrm{He}$ at $298 \mathrm{~K}$. It is clear that no dissociation products are observed consistent with the low injection energy used $(13.8 \mathrm{eV}, \mathrm{lab})$. In the presence of 0.25 Torr HCN vapor in the drift cell at $283 \mathrm{~K}$, the first two association products $\mathrm{C}_{5} \mathrm{H}_{5} \mathrm{~N}^{+} \cdot(\mathrm{HCN})_{\mathrm{n}}$ with $\mathrm{n}=1$ and 2 are observed as shown in Fig. 1(a). As the temperature decreases the ion intensity of $\mathrm{C}_{5} \mathrm{H}_{5} \mathrm{~N}^{+\cdot}$ significantly decreases and eventually disappears as the equilibrium shifts to higher $\mathrm{C}_{5} \mathrm{H}_{5} \mathrm{~N}^{+\cdot} \cdot(\mathrm{HCN})_{\mathrm{n}}$ clusters. At $194 \mathrm{~K}$, the cluster population is dominated by the $\mathrm{C}_{5} \mathrm{H}_{5} \mathrm{~N}^{+\cdot} \cdot(\mathrm{HCN})_{\mathrm{n}}$ ions with $\mathrm{n}=3$ and 4 . Similar results are obtained following the injection of the protonated pyridine into the drift cell containing $\mathrm{HCN}$ as shown in Fig. 1(b).

(b)

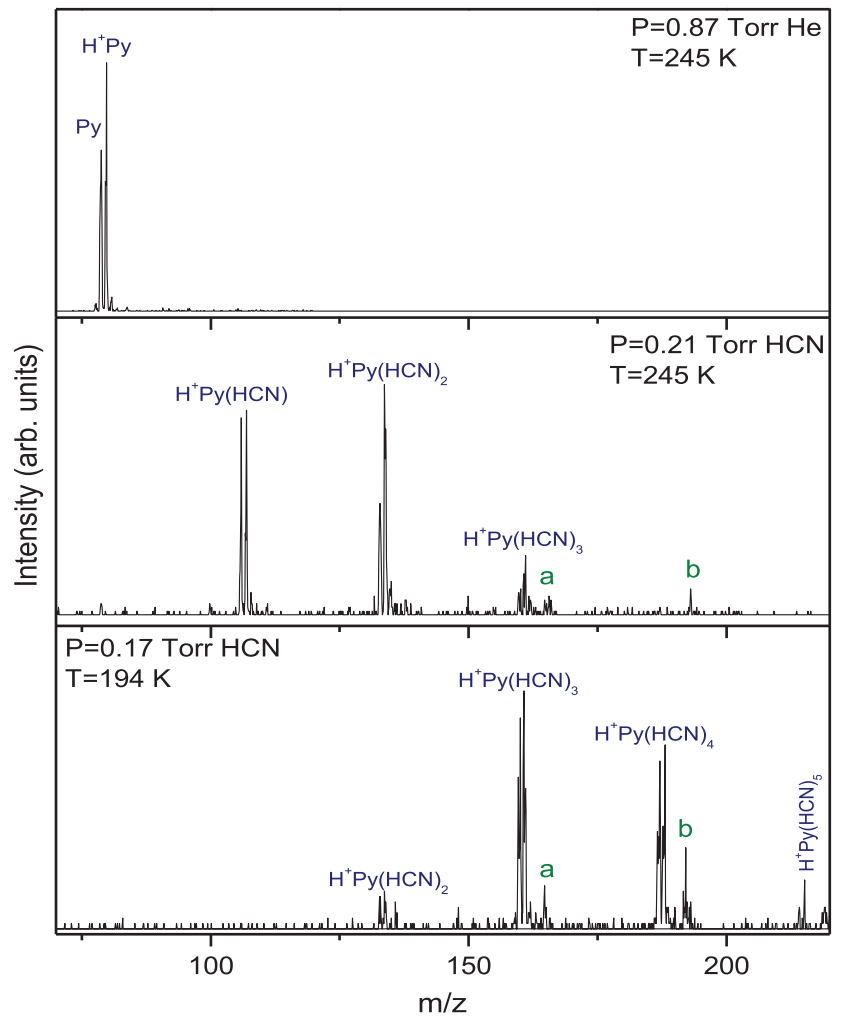

FIG. 1. (a) Mass spectra resulting from the injection of the mass-selected pyridine radical cation $\left(\mathrm{Py}^{+}\right)$into helium gas or $\mathrm{HCN}$ vapor at different temperatures using $13.8 \mathrm{eV}$ injection energy (laboratory frame) and $4 \mathrm{~V} / \mathrm{cm}$ applied field. (b) Mass spectra resulting from the injection of protonated pyridine $\left(\mathrm{H}^{+} \mathrm{Py}\right)$ into helium gas or $\mathrm{HCN}$ vapor at different temperatures using $14.2 \mathrm{eV}$ injection energy (laboratory frame) and $4 \mathrm{~V} / \mathrm{cm}$ applied field. The peaks labeled (a) $\mathrm{m} / \mathrm{z} 165$ and (b) $\mathrm{m} / \mathrm{z} 192$ are due to the association of $\mathrm{HCN}$ with a trace impurity $(\mathrm{m} / \mathrm{z} 138)$ present in the drift cell. 
(a)

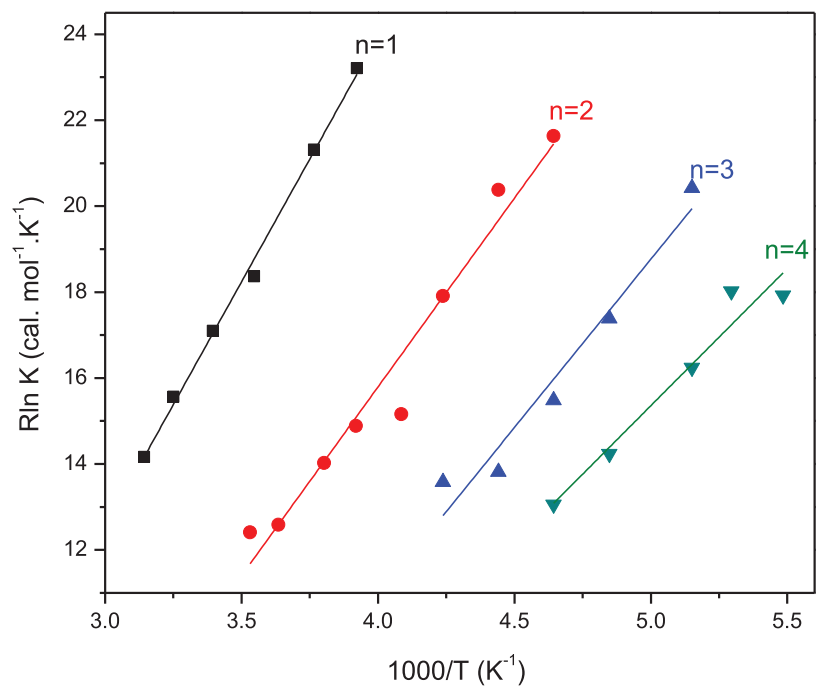

(b)

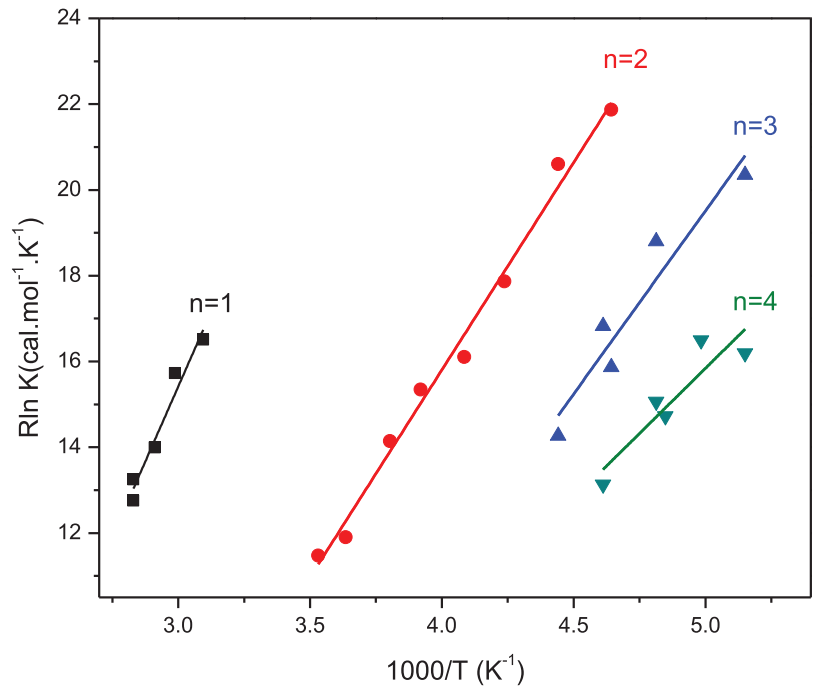

FIG. 2. van't Hoff plots of the temperature dependence of the equilibrium constants for the stepwise association of HCN with (a) the pyridine radical cation yielding $\mathrm{C}_{5} \mathrm{H}_{5} \mathrm{~N}^{+}(\mathrm{HCN})_{\mathrm{n}}$ with $\mathrm{n}=1-4$, and (b) protonated pyridine yielding $\mathrm{C}_{5} \mathrm{H}_{5} \mathrm{NH}^{+}(\mathrm{HCN})_{\mathrm{n}}$ with $\mathrm{n}=1-4$.

A good test of equilibrium comes from the identical ATDs of the ions coupled by equilibrium. If the $\mathrm{C}_{5} \mathrm{H}_{5} \mathrm{~N}^{+} \cdot(\mathrm{HCN})_{\mathrm{n}-1}$ and $\mathrm{C}_{5} \mathrm{H}_{5} \mathrm{~N}^{+} \cdot(\mathrm{HCN})_{\mathrm{n}}$ ions are in equilibrium, their ATDs must be identical. This is evident from the ATDs shown in Figure $\mathrm{S} 1$ of the supplementary material ${ }^{23}$ for the $\mathrm{C}_{5} \mathrm{H}_{5} \mathrm{~N}^{+} \cdot(\mathrm{HCN})_{\mathrm{n}}$ ions. The equilibrium constants for the stepwise association of $\mathrm{HCN}$ with $\mathrm{C}_{5} \mathrm{H}_{5} \mathrm{~N}^{+} \cdot$ and $\mathrm{C}_{5} \mathrm{H}_{5} \mathrm{NH}^{+}$measured at different temperatures yield the van't Hoff plots shown in Figures 2(a) and 2(b), respectively. The resulting $\Delta \mathrm{H}^{\mathrm{o}}$ and $\Delta \mathrm{S}^{\mathrm{o}}$ values for the formation of the $\mathrm{C}_{5} \mathrm{H}_{5} \mathrm{~N}^{+} \cdot(\mathrm{HCN})_{\mathrm{n}}$ and $\mathrm{C}_{5} \mathrm{H}_{5} \mathrm{NH}^{+}(\mathrm{HCN})_{\mathrm{n}}$ clusters are listed in Table I.

The sequential binding energies of $\mathrm{HCN}$ to the pyridine radical cation or to the protonated pyridine, shown in Table I, follow the trend of decreasing $\Delta \mathrm{H}^{\circ}{ }_{n-1, n}$ with increasing $\mathrm{n}$ which can be expected for association reactions dominated by ion-dipole interactions. ${ }^{4,15,16}$ Furthermore, the sequential entropy loss values are consistent with ion-dipole interactions where internal rotation and low frequency vibrations are retained. ${ }^{4,15-19}$ The thermochemical data also show that $\mathrm{HCN}$ binds more strongly to the protonated pyridine $\left(-\Delta \mathrm{H}^{\mathrm{o}}=14.0 \mathrm{kcal} / \mathrm{mol}\right)$ than to the pyridine radical cation $\left(-\Delta \mathrm{H}^{\mathrm{o}}=11.4 \mathrm{kcal} / \mathrm{mol}\right)$. However, the difference in binding between the radical cation and the protonated pyridine decreases as the number of HCN molecules increases which is expected since the charge-dipole interaction between protonated pyridine and the associated $\mathrm{HCN}$ molecule decreases with increasing the cluster size. Thus the binding energies for the $\mathrm{n}=4$ molecule in both the $\mathrm{C}_{5} \mathrm{H}_{5} \mathrm{~N}^{+} \cdot(\mathrm{HCN})_{\mathrm{n}}$ and $\mathrm{C}_{5} \mathrm{H}_{5} \mathrm{NH}^{+}(\mathrm{HCN})_{\mathrm{n}}$ clusters are essentially similar (6.4 and $6.1 \mathrm{kcal} / \mathrm{mol}$, respectively).

The DFT lowest energy structures of the $\mathrm{C}_{5} \mathrm{H}_{5} \mathrm{~N}^{+} \cdot(\mathrm{HCN})_{\mathrm{n}}$ and $\mathrm{C}_{5} \mathrm{H}_{5} \mathrm{NH}^{+}(\mathrm{HCN})_{\mathrm{n}}$ clusters with $\mathrm{n}$ $=1-4$ calculated at the M06-2X/6-311++G(d,p) are shown in Figures 3 and 4, respectively, and the binding energies calculated for the two lowest structures (within $2 \mathrm{kcal} / \mathrm{mol}$ ) are listed in Table I. The calculated binding energies agree reasonably with the measured $\left(-\Delta \mathrm{H}^{\circ}{ }_{\mathrm{n}-1, \mathrm{n}}\right)$ although in most cases, the binding energies of the second lowest energy structures appear to be in better agreement with the experimental values than the lowest energy structures.

Two isomers (1-a and 1-b) with binding energies of 11.9 and $11.4 \mathrm{kcal} / \mathrm{mol}$, respectively, are predicted for the $\mathrm{C}_{5} \mathrm{H}_{5} \mathrm{~N}^{+} \cdot(\mathrm{HCN})$ cluster as shown in Fig. 3. These binding energies are in excellent agreement with the experimental value of $11.4 \mathrm{kcal} / \mathrm{mol}$. Both structures show H-bonding between the $\mathrm{C}-\mathrm{H}^{\delta} \ldots$ of the pyridine cation and the $\mathrm{N}$ atom of HCN. However isomer (a) has a bifurcated structure with the $\mathrm{N}$-atom of $\mathrm{HCN}$ forming two long H-bonds $(2.56 \AA$ and $2.34 \AA$ ) with the ortho- and meta- $\mathrm{CH}$ groups of the pyridine cation. This structure is similar to the lowest energy isomer of the benzene $+\cdot(\mathrm{HCN})$ cluster. $^{17}$ The second lowest energy isomer (b) has a $2.07 \AA$ hydrogen bond between the $\mathrm{N}$-atom of $\mathrm{HCN}$ and the ortho-aromatic hydrogen atom. The third most stable isomer (1-c) has the $\mathrm{HCN}$ molecule attached to the para-aromatic hydrogen atom via $2.2 \AA$ hydrogen bond. This isomer is $2.7 \mathrm{kcal} / \mathrm{mol}$ higher in energy than isomer $1-\mathrm{a}$, and therefore, it gives a binding energy significantly lower $(9.3 \mathrm{kcal} / \mathrm{mol})$ than the experimental value of $11.4 \mathrm{kcal} / \mathrm{mol}$. The three lowest energy structures of the $\mathrm{C}_{5} \mathrm{H}_{5} \mathrm{~N}^{+} \cdot(\mathrm{HCN})$ cluster confirm that the interaction of $\mathrm{HCN}$ with the pyridine cation is dominated by hydrogen bonding between the $\mathrm{N}$ of $\mathrm{HCN}$ and the ring $\mathrm{H}$ atom. In spite of the acidic character of the $\mathrm{H}$ atom of $\mathrm{HCN}$, no hydrogen bonding is observed to the $\mathrm{N}$ atom of the pyridine cation which carries a net positive charge as shown by the charge density distribution (Figure S2 of the supplementary material). ${ }^{23}$

The lowest energy structures of $\mathrm{C}_{5} \mathrm{H}_{5} \mathrm{~N}^{+} \cdot(\mathrm{HCN})_{\mathrm{n}}$ clusters with $n=2-4$ show a tendency for the internal solvation of the pyridine cation by the HCN molecules where bifurcated structures involving multiple hydrogen bonding sites with the ring hydrogen atoms are formed such as shown in structures (2-a), (3-a), (3-b), (4-a), and (4-b). Structures (2-b) and (3-c) 


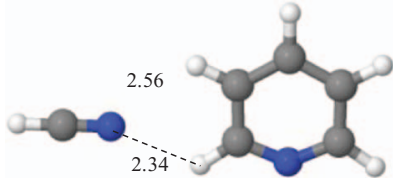

(1-a)

$\mathrm{RE}=0.0$

$\Delta \mathrm{E}=11.9$

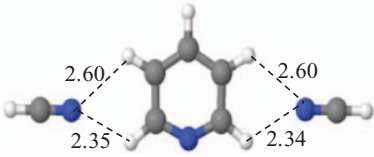

(2-a)

$\mathrm{RE}=0.0$

$\Delta \mathrm{E}=10.9$

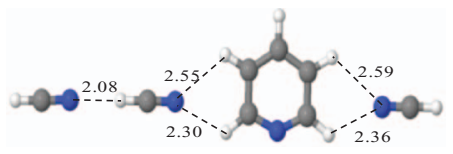

(3-a)

$\mathrm{RE}=0.0$

$\Delta \mathrm{E}=10.6$

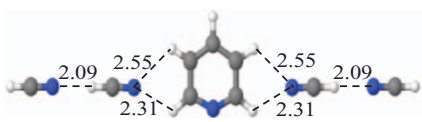

(4-a)

$\mathrm{RE}=0.0$

$\Delta \mathrm{E}=8.7$

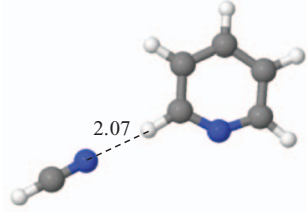

(1-b)

$\mathrm{RE}=0.5$

$\Delta \mathrm{E}=11.4$

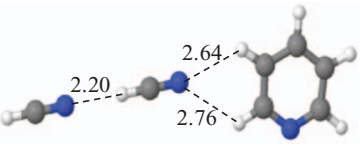

(2-b)

$\mathrm{RE}=1.6$

$\Delta \mathrm{E}=9.4$

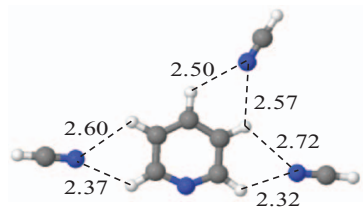

(3-b)

$\mathrm{RE}=0.8$

$\Delta \mathrm{E}=9.6$

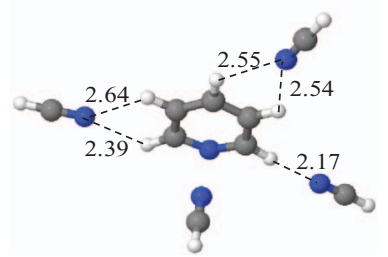

(4-b)

$\mathrm{RE}=1.5$

$\Delta \mathrm{E}=6.8$

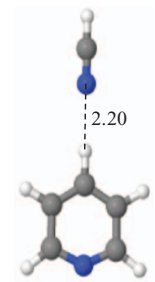

(1-c)

$\mathrm{RE}=2.7$

$\Delta \mathrm{E}=9.3$

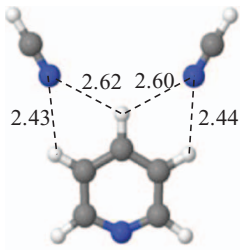

(2-c)

$\mathrm{RE}=3.2$

$\Delta \mathrm{E}=7.7$

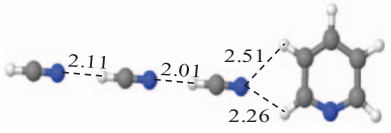

(3-c)

$\mathrm{RE}=2.6$

$\Delta \mathrm{E}=8.2$

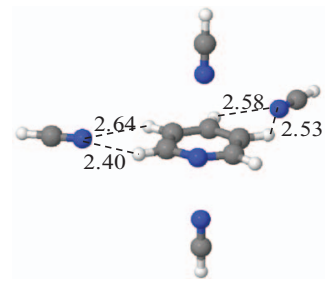

(4-c)

$\mathrm{RE}=2.0$

$\Delta \mathrm{E}=6.1$

FIG. 3. Structures of pyridine ${ }^{+} \cdot(\mathrm{HCN})_{1-4}$ calculated by DFT at the M06-2x/6-311++G (d,p) level. Relative energies (RE) are the total electronic energies with respect to the lowest energy isomer (0.0). Binding energies $(\Delta \mathrm{E})$ are corrected for zero-point energies (ZPE) and basis-set super position errors (BSSE). Energies are in $\mathrm{kcal} / \mathrm{mol}$. Distances are in Angstrom.

show the formation of hydrogen bonding chains involving two or three $\mathrm{HCN}$ molecules, respectively, attached to the pyridine cation through bifurcated structures. However, no chain structures involving four $\mathrm{HCN}$ molecules have been found in the $\mathrm{C}_{5} \mathrm{H}_{5} \mathrm{~N}^{+\cdot}(\mathrm{HCN})_{4}$ clusters indicating that $\mathrm{HCN}$ interactions with the pyridine ring are more favorable than the interactions within the HCN chains. It is interesting to note that the chain structures (2-b, $\Delta \mathrm{E}=9.4 \mathrm{kcal} / \mathrm{mol})$ and (3-c, $\Delta \mathrm{E}=8.2$ $\mathrm{kcal} / \mathrm{mol}$ ) show good agreement with the measured binding energies $(8.8$ and $7.8 \mathrm{kcal} / \mathrm{mol}$, respectively) unlike the solvated pyridine structures $(2-\mathrm{a}, \Delta \mathrm{E}=10.9 \mathrm{kcal} / \mathrm{mol})$ and $(3-\mathrm{a}$, $\Delta \mathrm{E}=10.6 \mathrm{kcal} / \mathrm{mol}$ ) which tend to overestimate the binding energies. On the other hand, for the $\mathrm{C}_{5} \mathrm{H}_{5} \mathrm{~N}^{+} \cdot(\mathrm{HCN})_{4}$ cluster the solvated pyridine structures $(4-\mathrm{b}, \Delta \mathrm{E}=6.8 \mathrm{kcal} / \mathrm{mol})$ and $(4-\mathrm{c}, \Delta \mathrm{E}=6.1 \mathrm{kcal} / \mathrm{mol})$ are in good agreement with the measured binding energy of $6.4 \mathrm{kcal} / \mathrm{mol}$.

The lowest energy structures of the $\mathrm{HCN}$ molecules associated with the protonated pyridine in the $\mathrm{C}_{5} \mathrm{H}_{5} \mathrm{NH}^{+}(\mathrm{HCN})_{\mathrm{n}}$ clusters are dominated by conventional IHBs between the $\mathrm{NH}^{+}$group of the protonated pyridine and the nitrogen atom of $\mathrm{HCN}$ as shown in all structures displayed in Fig. 4 except structures (1-b) and (1-c). These high energy structures exhibit significantly lower binding energies (1-b and 1-c, $\Delta \mathrm{E}=9.2$ and $8.1 \mathrm{kcal} / \mathrm{mol}$, respectively) as compared to the experimental value of $14.0 \mathrm{kcal} / \mathrm{mol}$ for the $\mathrm{C}_{5} \mathrm{H}_{5} \mathrm{NH}^{+}(\mathrm{HCN})$ cluster. Interestingly, $\mathrm{HCN}$ extended chain structures are more frequent among the $\mathrm{C}_{5} \mathrm{H}_{5} \mathrm{NH}^{+}(\mathrm{HCN})_{\mathrm{n}}$ clusters as shown by the low energy structures (2-b), (3-c), and (4-c). 


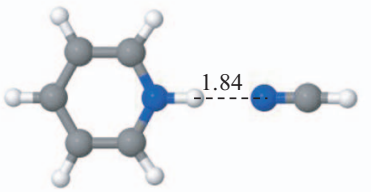

(1-a)

$\mathrm{RE}=0.0$

$\Delta \mathrm{E}=16.0$

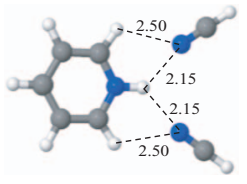

(2-a)

$\mathrm{RE}=0.0$

$\Delta \mathrm{E}=12.0$

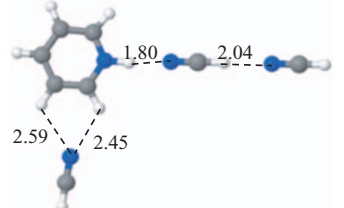

(3-a)

$\mathrm{RE}=0.0$

$\Delta \mathrm{E}=8.1$

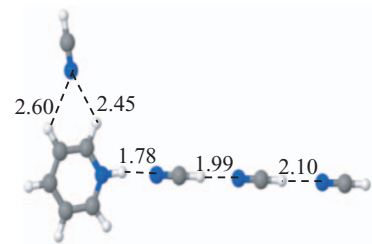

(4-a)

$\mathrm{RE}=0.0$

$\Delta \mathrm{E}=8.4$

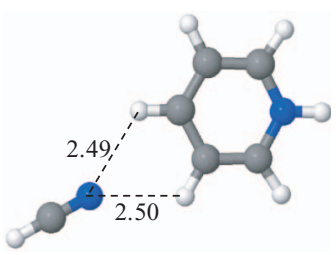

(1-b)

$\mathrm{RE}=6.8$

$\Delta \mathrm{E}=9.2$

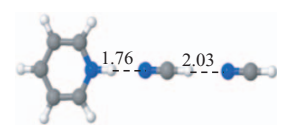

(2-b)

$\mathrm{RE}=1.1$

$\Delta \mathrm{E}=11.3$

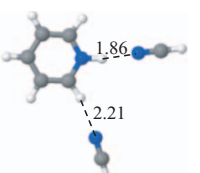

(2-c)

$\mathrm{RE}=3.0$

$\Delta \mathrm{E}=9.3$

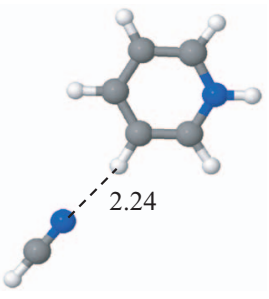

(1-c)

$\mathrm{RE}=7.0$

$\Delta \mathrm{E}=8.1$

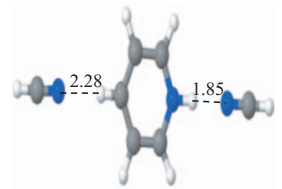

(2-d)

$\mathrm{RE}=3.9$

$\Delta \mathrm{E}=8.3$

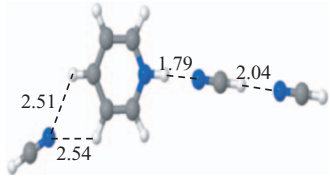

(3-b)

$\mathrm{RE}=0.5$

$\Delta \mathrm{E}=7.6$

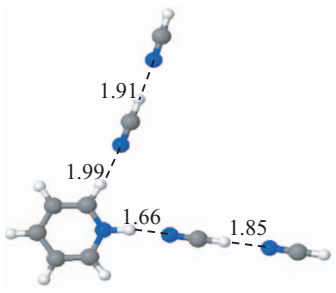

(4-b)

$\mathrm{RE}=0.4$

$\Delta \mathrm{E}=7.2$

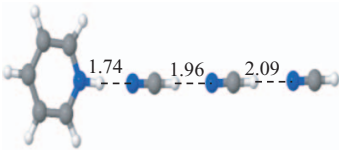

(3-c)

$\mathrm{RE}=0.5$

$\Delta \mathrm{E}=7.8$

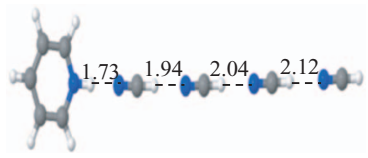

(4-c)

$\mathrm{RE}=1.4$

$\Delta \mathrm{E}=7.4$

FIG. 4. Structures of pyridine $\mathrm{H}^{+}(\mathrm{HCN})_{1-4}$ calculated by DFT at the M06-2x/6-311++G (d,p) level. Relative energies (RE) are the total electronic energies with respect to the lowest energy isomer $(0.0)$. Binding energies $(\Delta \mathrm{E})$ are corrected for zero-point energies (ZPE) and basis-set super position errors (BSSE). Energies are in $\mathrm{kcal} / \mathrm{mol}$. Distances are in Angstrom.

\section{B. Association of $\mathrm{HCN}$ with the pyrimidine radical cation}

Figure 5 displays the mass spectra obtained following the injection of the mass-selected pyrimidine ion into the drift cell containing either pure $\mathrm{He}$ or $\mathrm{HCN}$ vapor at different temperatures. The first association product $\mathrm{C}_{4} \mathrm{H}_{4} \mathrm{~N}_{2}+\cdot(\mathrm{HCN})$ is observed with 0.2 Torr $\mathrm{HCN}$ at $274 \mathrm{~K}$ and as the temperature of the drift cell decreases higher association products $\mathrm{C}_{4} \mathrm{H}_{4} \mathrm{~N}_{2}+\cdot(\mathrm{HCN})_{n}$ with $\mathrm{n}$ up to 4 are observed as shown in Fig. 5. The ATDs of the $\mathrm{C}_{4} \mathrm{H}_{4} \mathrm{~N}_{2}+\cdot(\mathrm{HCN})_{\mathrm{n}-1}$ and $\mathrm{C}_{4} \mathrm{H}_{4} \mathrm{~N}_{2}{ }^{+\cdot}(\mathrm{HCN})_{\mathrm{n}}$ ions indicate the establishment of equilibrium as shown in Figure S3 of the supplementary material. ${ }^{23}$ The equilibrium constants for the stepwise association of $\mathrm{HCN}$ with $\mathrm{C}_{4} \mathrm{H}_{4} \mathrm{~N}_{2}{ }^{+\cdot}$ measured at different tem- peratures yield the van't Hoff plots shown in Figure 6, and the resulting $\Delta \mathrm{H}^{\mathrm{o}}$ and $\Delta \mathrm{S}^{\mathrm{o}}$ values for the formation of the $\mathrm{C}_{4} \mathrm{H}_{4} \mathrm{~N}_{2}+\cdot(\mathrm{HCN})_{\mathrm{n}}$ clusters and calculated binding energies at the M06-2X/6-311++G(d,p) are listed in Table II.

The binding energy of $\mathrm{HCN}$ to the pyrimidine radical cation $(12 \mathrm{kcal} / \mathrm{mol})$ is slightly higher than the corresponding value for the pyridine cation $(11.4 \mathrm{kcal} / \mathrm{mol})$ and lower than that of the protonated pyridine $(14.0 \mathrm{kcal} / \mathrm{mol})$. This indicates that $\mathrm{HCN}$ binds to the pyrimidine cation via a $\mathrm{CH}^{\delta+} \ldots \mathrm{NCH}$ unconventional hydrogen bond, which is relatively weaker than the IHB $\mathrm{NH}^{+} \ldots \mathrm{NCH}$ formed with the protonated pyridine. This also indicates that the pyrimidine cation in our experiments has the conventional radical cation structure $\left(\mathrm{C}_{4} \mathrm{H}_{4} \mathrm{~N}_{2}{ }^{+\cdot}\right)$ and not the distonic structure $\left(\mathrm{C}_{4} \mathrm{H}_{3} \mathrm{NNH}^{+}\right)$which would bind stronger to $\mathrm{HCN}$. 


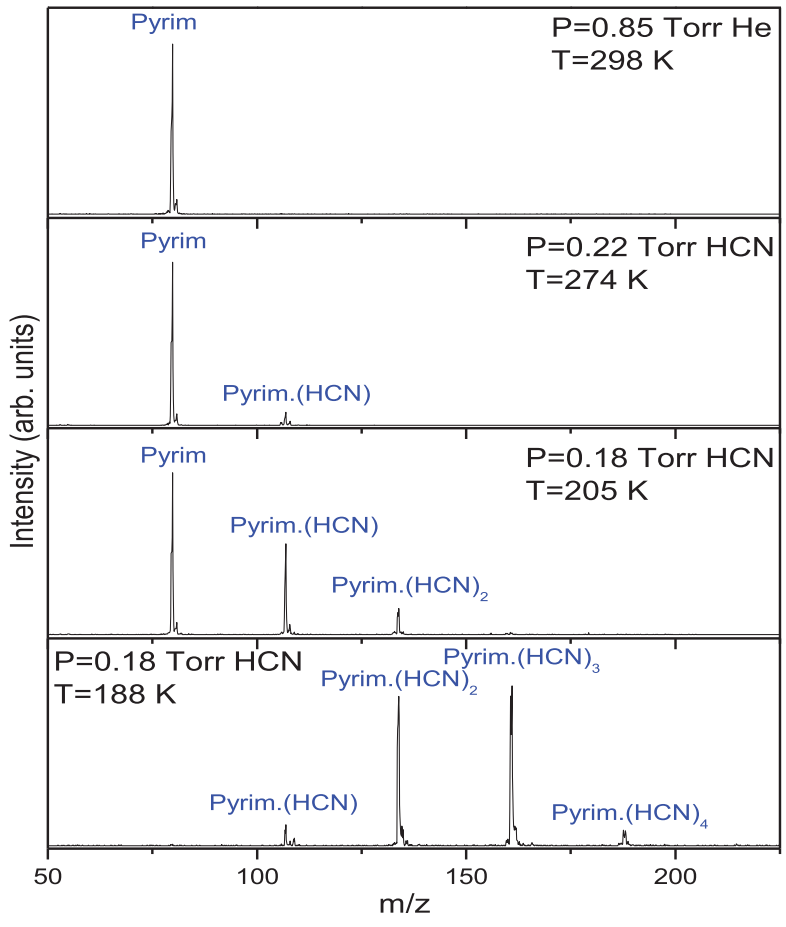

FIG. 5. Mass spectra resulting from the injection of the mass-selected pyrimidine radical cation (Pyrim) into helium gas or HCN vapor at different temperatures using $12.4 \mathrm{eV}$ injection energy (laboratory frame) and $4 \mathrm{~V} / \mathrm{cm}$ applied field.

The DFT lowest energy structures of the $\mathrm{C}_{4} \mathrm{H}_{4} \mathrm{~N}_{2}+\cdot(\mathrm{HCN})_{\mathrm{n}}$ clusters with $\mathrm{n}=1-4$ calculated at the M06-2X/6-311++G(d,p) are shown in Figure 7. The lowest energy structure of the $\mathrm{C}_{4} \mathrm{H}_{4} \mathrm{~N}_{2}+\cdot(\mathrm{HCN})$ complex has a T-shaped ion-dipole structure with the $\mathrm{N}$ atom of $\mathrm{HCN}$ pointing toward the center of the pyrimidine cation ring. The second and third lowest energy structures represent unconventional $\mathrm{CH}^{\delta+} \ldots \mathrm{NCH}$ hydrogen bonds similar to the structures found for the $\mathrm{C}_{5} \mathrm{H}_{5} \mathrm{~N}^{+} \cdot(\mathrm{HCN})$ complex shown in Fig. 3. The strongest $\mathrm{H}$ donor site in the pyrimidine cation

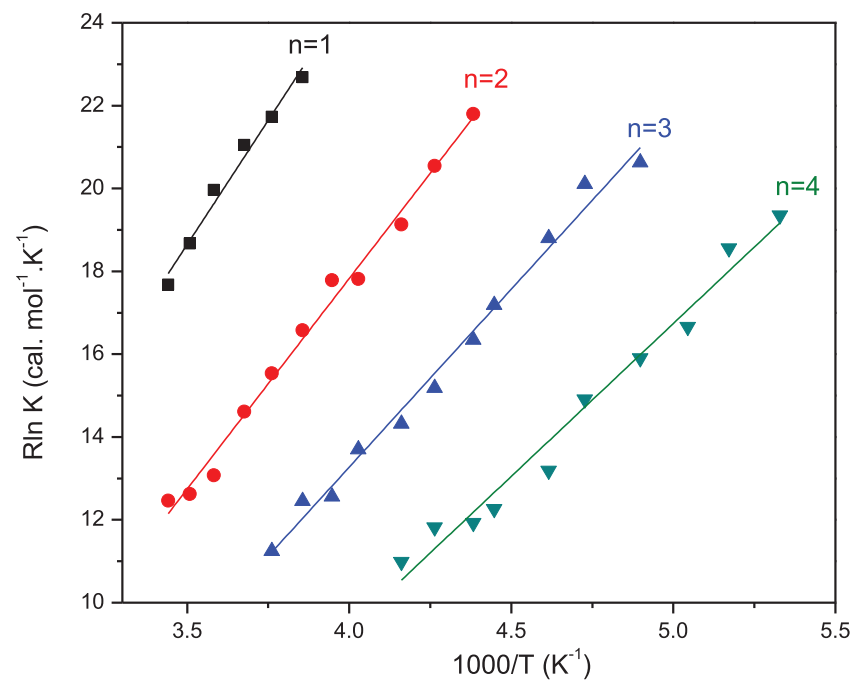

FIG. 6. van't Hoff plots of the temperature dependence of the equilibrium constants for the stepwise association of $\mathrm{HCN}$ with the pyrimidine radical cation yielding $\mathrm{C}_{5} \mathrm{H}_{4} \mathrm{~N}_{2}{ }^{+}(\mathrm{HCN})_{\mathrm{n}}$ with $\mathrm{n}=1-4$.
TABLE II. Measured thermochemistry $\left(-\Delta \mathrm{H}^{\circ}{ }_{\mathrm{n}-1, \mathrm{n}}\right.$ and $\left.-\Delta \mathrm{S}_{\mathrm{n}-1, \mathrm{n}}\right)$ of the formation of $\mathrm{C}_{5} \mathrm{H}_{4} \mathrm{~N}_{2}+\cdot(\mathrm{HCN})_{n}$ clusters; with $\mathrm{n}=1-4$ and the corresponding calculated binding energies for the lowest energy structures.

\begin{tabular}{lccc}
\hline \hline \multicolumn{3}{c}{ Pyrimidine $^{+\cdot}(\mathrm{HCN})_{\mathrm{n}}$} \\
\hline $\mathrm{n}$ & $-\Delta \mathrm{H}^{\mathrm{oa}}$ & $-\Delta \mathrm{S}^{\text {ob }}$ & $\Delta \mathrm{E}(\mathrm{M} 06-2 \mathrm{X})^{\mathrm{c}}$ \\
\hline 1 & 12.0 & 23.3 & 12.7 \\
2 & 10.2 & 22.8 & 9.6 \\
3 & 8.6 & 21.1 & 10.7 \\
4 & 7.4 & 20.2 & 8.8 \\
\hline \hline
\end{tabular}

${ }^{\mathrm{a}} \Delta \mathrm{H}_{\mathrm{n}-1, \mathrm{n}}^{\circ}$ units are $\mathrm{kcal} / \mathrm{mol}$.

${ }^{b} \Delta S^{\circ}{ }_{n-1, n}$ units are cal/mol K. Error estimate for experimental values from standard deviations of van't Hoff and from usual uncertainties in clustering equilibrium temperature studies: $\Delta \mathrm{H}^{\circ} \pm 1 \mathrm{kcal} / \mathrm{mol}, \Delta \mathrm{S}^{\circ} \pm 2 \mathrm{cal} / \mathrm{mol} \mathrm{K}$.

${ }^{c}$ Binding energy calculated at the M06-2X/6-311++G(d,p) level with ZPE and BSSE corrections included.

is the one located between the two nitrogen atoms of the ring and this site appears to form most of the non-bifurcated $\mathrm{H}$ bonds with the nitrogen atom of the $\mathrm{HCN}$ molecule. The calculated binding energies of $\mathrm{C}_{4} \mathrm{H}_{4} \mathrm{~N}_{2}+\cdot(\mathrm{HCN})_{1-4}$ clusters agree reasonably with the measured $\left(-\Delta \mathrm{H}_{\mathrm{n}-1, \mathrm{n}}^{\circ}\right)$ except for the $\mathrm{C}_{4} \mathrm{H}_{4} \mathrm{~N}_{2}+\cdot(\mathrm{HCN})_{3}$ cluster where the calculated binding energy $(10.7 \mathrm{kcal} / \mathrm{mol})$ is significantly higher than the measured $-\Delta \mathrm{H}_{2,3}^{\circ}$ value of $8.6 \mathrm{kcal} / \mathrm{mol}$. This could indicate that the structure of the $\mathrm{C}_{4} \mathrm{H}_{4} \mathrm{~N}_{2}+\cdot(\mathrm{HCN})_{3}$ cluster formed under our experimental conditions may be different from the calculated lowest energy structure which has the bifurcated hydrogen bonding structures of one HCN molecule to two $\mathrm{CH}^{\delta+}$ groups of the ring and also two T-shaped ion-dipole structures involving two HCN molecules. This complicated structure may be kinetically unfavorable since the collisions of $\mathrm{HCN}$ molecules with the lowest energy structure of the $\mathrm{C}_{4} \mathrm{H}_{4} \mathrm{~N}_{2}{ }^{+\cdot}(\mathrm{HCN})_{2}$ cluster (structure (2-a), Fig. 7) to form structure (3-b) do not require further rearrangements of the HCN molecules as in the case of structure (3-a).

Similar to the trend observed in the structures of the pyridine ${ }^{+}(\mathrm{HCN})_{\mathrm{n}}$ clusters, the formation of the solvated cation structures are also observed in the pyrimidine $^{+\cdot}(\mathrm{HCN})_{n}$ clusters as shown in structures (4-a), (4-b), and (4-c) displayed in Fig. 7 for the $\mathrm{n}=4$ cluster.

\section{Comparison with the MP2/6-311++G(d,p) level calculations}

In order to compare the results of the DFT/M06$2 \mathrm{X} / 6-311++\mathrm{G}(\mathrm{d}, \mathrm{p})$ calculations with a different method, we carried out calculations on the $\mathrm{C}_{5} \mathrm{H}_{5} \mathrm{~N}^{+} \cdot(\mathrm{HCN})$, $\mathrm{C}_{5} \mathrm{H}_{5} \mathrm{NH}^{+}(\mathrm{HCN})$, and $\mathrm{C}_{4} \mathrm{H}_{4} \mathrm{~N}_{2}+\cdot(\mathrm{HCN})$ complexes at the MP2/6-311++G(d,p) level. ${ }^{22}$ The calculated lowest energy structures, their relative energies, and binding energies of the complexes are shown in Figure 8. The three lowest energy structures of the pyridine ${ }^{+}$and protonated pyridine complexes with HCN are similar at both the DFT/M06-2X/6$311++\mathrm{G}(\mathrm{d}, \mathrm{p})$ and MP2/M06-2X/6-311++G(d,p) levels as shown by comparing the results shown in Figures 3, 4, and 8. The calculated binding energies using the two methods are also similar. Interestingly, the overestimated binding energy of the pyridine $\mathrm{H}^{+}(\mathrm{HCN})$ complex $(16 \mathrm{kcal} / \mathrm{mol}$ with the 


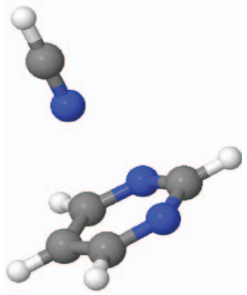

(1-a)

$\mathrm{RE}=0.0$

$\Delta \mathrm{E}=12.7$

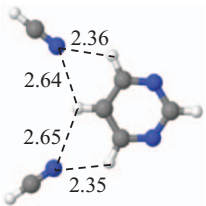

(2-a)

$\mathrm{RE}=0.0$

$\Delta \mathrm{E}=9.6$

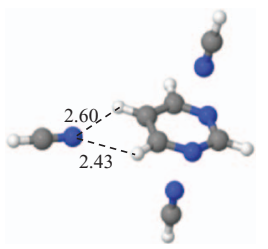

(3-a)

$\mathrm{RE}=0.0$

$\Delta \mathrm{E}=10.7$

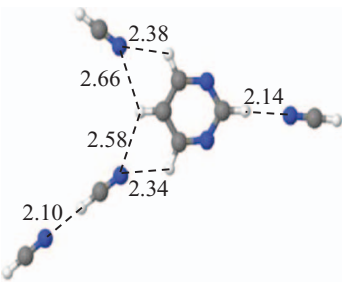

(4-a)

$\mathrm{RE}=0.0$

$\Delta \mathrm{E}=8.8$

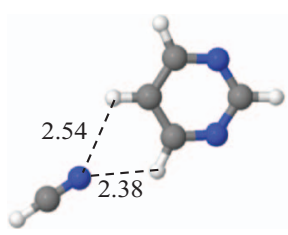

(1-b)

$\mathrm{RE}=0.7$

$\Delta \mathrm{E}=12.3$

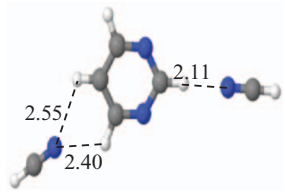

(2-b)

$\mathrm{RE}=0.2$

$\Delta \mathrm{E}=9.4$

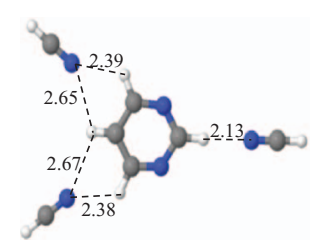

(3-b)

$\mathrm{RE}=1.8$

$\Delta \mathrm{E}=9.2$

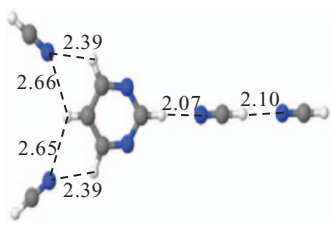

(4-b)

$\mathrm{RE}=0.4$

$\Delta \mathrm{E}=7.7$

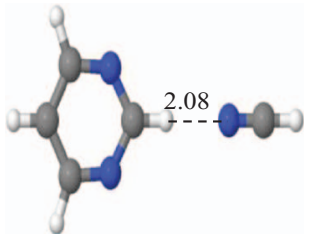

(1-c)

$\mathrm{RE}=1.8$

$\Delta \mathrm{E}=11.2$

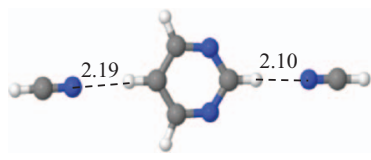

(2-c)

$\mathrm{RE}=1.9$

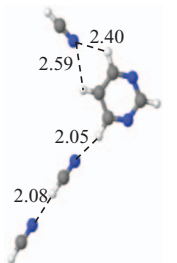

(3-c)

$\mathrm{RE}=2.9$

$\Delta \mathrm{E}=8.0$

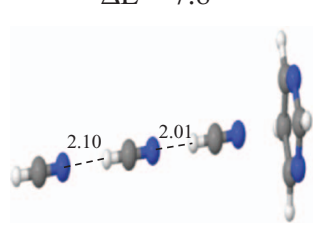

(3-d)

$\mathrm{RE}=3.5$

$\Delta \mathrm{E}=7.0$

FIG. 7. Structures of the pyrimidine ${ }^{+} \cdot(\mathrm{HCN})_{1-4}$ clusters calculated by DFT at the M06-2x/6-311++G $(\mathrm{d}, \mathrm{p})$ level. Relative energies (RE) are the total electronic energies with respect to the lowest energy isomer (0.0). Binding energies $(\triangle \mathrm{E})$ are corrected for zero-point energies (ZPE) and basis-set super position errors (BSSE). Energies are in $\mathrm{kcal} / \mathrm{mol}$. Distances are in Angstrom.

DFT/M06-2X/6-311++G(d,p) method as compared to the experimental value of $14 \mathrm{kcal} / \mathrm{mol})$ is also found using the MP2/M06-2X/6-311++G(d,p) method. This confirms the accuracy of the calculations and could suggest that the experimentally measured value may have some contribution from the lower binding energy pyridine ${ }^{+} \cdot(\mathrm{HCN})$ complex $\left(-\Delta \mathrm{H}^{\mathrm{o}}\right.$ $=11.4 \mathrm{kcal} / \mathrm{mol}$, Table I). Considering the mass difference between the pyridine $\mathrm{H}^{+}(\mathrm{HCN})$ and pyridine ${ }^{+\cdot}(\mathrm{HCN})$ complexes is only $1 \mathrm{amu}$, the possibility of having a mixture of the pyridine radical cation and protonated pyridine in the experiment cannot be eliminated.

The only major difference between the DFT and MP2 results is the order of the lowest energy structures of the pyrimidine $+\cdot(\mathrm{HCN})$ complex as shown from the comparison between the results shown in Figures 7 and 8 . While DFT predicts a T-shaped ion-dipole structure for the $\mathrm{C}_{4} \mathrm{H}_{4} \mathrm{~N}_{2}+\cdot(\mathrm{HCN})$ complex (structure (1-a), Figure 7), the MP2 method shows the unconventional hydrogen bonding structure $\left(\mathrm{CH}^{\delta+} \ldots \mathrm{NCH}\right)$ to be the lowest energy isomer (structure 1-a-pyrimidine ${ }^{+\cdot}(\mathrm{HCN})$, Figure 8$)$. With the DFT method, the hydrogen bonding structure was the second lowest energy structure (structure (1-b)) with only $0.4 \mathrm{kcal} / \mathrm{mol}$ lower binding energy than the T-shaped structure (structure (1-a)) as shown in Figure 7. However, with the MP2 method the T-shaped structure has substantially lower binding energy $(8.3 \mathrm{kcal} / \mathrm{mol}$, structure 1-c-pyrimidine $+\cdot(\mathrm{HCN}))$ as compared to the hydrogen bonding structure $(12.2 \mathrm{kcal} / \mathrm{mol}$, structure $1-\mathrm{a})$ as shown in Figure 8 for the pyrimidine $+\cdot(\mathrm{HCN})$ complex. This indicates that the hydrogen bonding structure ((1-b) in Fig. 7 and 1-a, third row in Fig. 8) is most likely the lowest energy structure for the pyrimidine ${ }^{+} \cdot(\mathrm{HCN})$ complex. This could also 


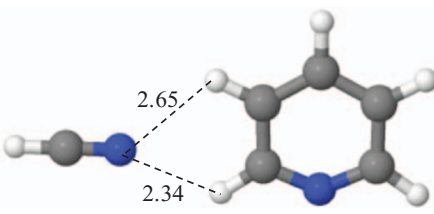

(1-a)

$\mathrm{RE}=0.0$

$\Delta \mathrm{E}=11.3$

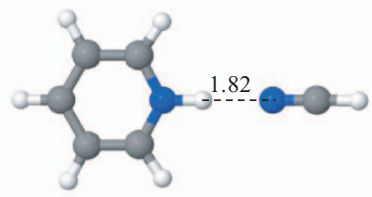

(1-a)

$\mathrm{RE}=0.0$

$\Delta \mathrm{E}=16.5$

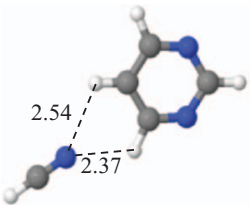

(1-a)

$\mathrm{RE}=0.0$

$\Delta \mathrm{E}=12.2$

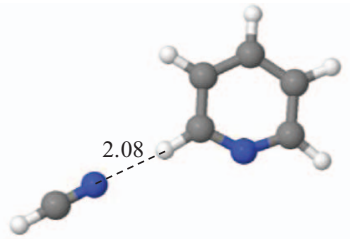

(1-b)

$\mathrm{RE}=0.5$

$\Delta \mathrm{E}=11.2$

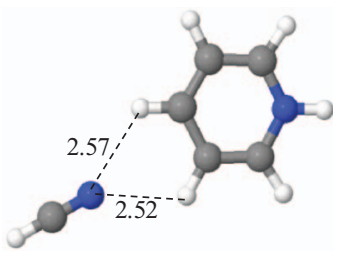

(1-b)

$\mathrm{RE}=6.8$

$\Delta \mathrm{E}=9.2$

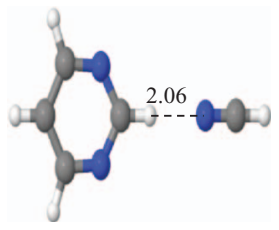

(1-b)

$\mathrm{RE}=0.2$

$\Delta \mathrm{E}=11.1$

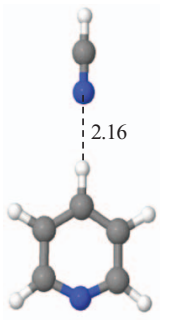

(1-c)

$\mathrm{RE}=2.7$

$\Delta \mathrm{E}=10.3$

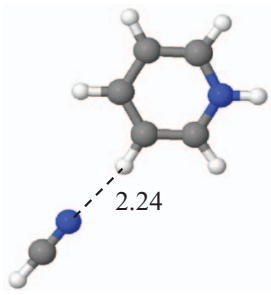

(1-c)

$\mathrm{RE}=7.8$

$\Delta \mathrm{E}=9.2$

FIG. 8. Structures of the pyridine ${ }^{+} \cdot(\mathrm{HCN})$, pyridine $\mathrm{H}^{+}(\mathrm{HCN})$, and pyrimidine ${ }^{+} \cdot(\mathrm{HCN})$ clusters calculated at the MP2/6-311++G(d,p) level. Relative energies $(\mathrm{RE})$ are the total electronic energies with respect to the lowest energy isomer $(0.0)$. Binding energies $(\triangle \mathrm{E})$ are corrected for zero-point energies $(\mathrm{ZPE})$ and basis-set super position errors (BSSE). Energies are in kcal/mol. Distances are in Angstrom.

suggest that the ion-dipole interaction is either underestimated or overestimated with the MP2 and DFT methods, respectively.

\section{Comparison of $\mathrm{HCN}$ interactions with the benzene, pyridine, pyrimidine radical cations, and protonated pyridine}

Table III shows a comparison of the sequential binding energies of 1-4 $\mathrm{HCN}$ molecules to the benzene, pyridine and pyrimidine radical cations, and the protonated pyridine. Figure 9 compares the trends in binding energies for the four ions. The binding of $\mathrm{HCN}$ molecules to the benzene cation is mostly due to unconventional $\mathrm{CH}^{\delta+} \ldots \mathrm{NCH}$ hydrogen bonds directly connected to the $\mathrm{CH}^{\delta+}$ sites of the benzene cation and also hydrogen bonding chains $(\mathrm{HCN} \cdots \mathrm{HCN})$ among the HCN molecules. The small difference in the bond strength of the two types of interactions results in relatively small changes of $\left(-\Delta \mathrm{H}^{\circ}{ }_{n-1, n}\right)$ for $\mathrm{n}=1-4$ as shown in Fig. 9. HCN binds more strongly to the pyridine and pyrimidine radical cations due to the presence of stronger ion-dipole interactions in addition to the $\mathrm{CH}^{\delta+}-\mathrm{NCH}$ hydrogen bonding interactions. The strongest binding is observed between the protonated pyridine and HCN as a result of IHB that forms between the $\mathrm{NH}^{+}$group of the protonated pyridine and the $\mathrm{N}$ atom of $\mathrm{HCN}$. A significant drop in the binding energy (31\%) is observed upon the addition of the second HCN molecule to the protonated pyridine in contrast to the smaller changes observed upon the addition of the second $\mathrm{HCN}$ molecule to the pyridine or pyrimidine radical cations $(23 \%$, and $15 \%$, respectively) as shown in Fig. 9. Despite the strong bonding of $\mathrm{HCN}$ to protonated pyridine, the interaction decreases sharply by further addition of $\mathrm{HCN}$ molecules and terminal binding for the fourth $\mathrm{HCN}$ molecule is only $6.1 \mathrm{kcal} / \mathrm{mol}$. In fact, in all of the studied HCN clusters around ionized or protonated aromatics, ${ }^{17-19}$ the binding energies converge with the addition of 4-5 HCN molecules to the enthalpy of vaporization of $\mathrm{HCN}$ liquid $\left(\Delta \mathrm{H}^{\circ}{ }_{\text {vap }}\right)$, which is $6.0 \mathrm{kcal} / \mathrm{mol}$ at $298 \mathrm{~K} .{ }^{24}$

As indicated earlier, $\mathrm{HCN}$ is a useful probe of noncovalent interactions because it can serve both as a hydrogen donor and as a lone-pair hydrogen acceptor in 
TABLE III. Measured binding energies $\left(-\Delta \mathrm{H}^{\circ}{ }_{\mathrm{n}-1, \mathrm{n}}, \mathrm{kcal} / \mathrm{mol}\right)$ of the stepwise association of 1-4 HCN molecules with the benzene, pyridine and pyrimidine radical cations, and protonated pyridine.

\begin{tabular}{lcccc}
\hline \hline \multicolumn{5}{c}{$-\Delta \mathrm{H}^{\mathrm{o}}\left[\mathrm{X}^{+}(\mathrm{HCN})_{\mathrm{n}}\right]^{\mathrm{a}}$} \\
\hline $\mathrm{n}$ & $\begin{array}{c}\text { Benzene radical } \\
\text { cation }^{\mathrm{b}}\end{array}$ & $\begin{array}{c}\text { Pyridine radical } \\
\text { cation }\end{array}$ & $\begin{array}{c}\text { Pyrimidine radical } \\
\text { cation }\end{array}$ & $\begin{array}{c}\text { Protonated } \\
\text { pyridine }\end{array}$ \\
\hline 1 & 9.2 & 11.4 & 12.0 & 14.0 \\
2 & 8.0 & 8.8 & 10.2 & 9.7 \\
3 & 7.5 & 7.8 & 8.6 & 8.5 \\
4 & 7.3 & 6.4 & 7.4 & 6.1 \\
\hline \hline
\end{tabular}

${ }^{a}$ Error estimate for experimental values from standard deviations of van't Hoff and from usual uncertainties in clustering equilibrium temperature studies: $\Delta \mathrm{H}^{\circ} \pm 1 \mathrm{kcal} / \mathrm{mol}$, $\Delta \mathrm{S}^{\circ} \pm 2 \mathrm{cal} / \mathrm{mol} \mathrm{K}$.

${ }^{\mathrm{b}}$ Reference 17 .

different types of hydrogen bonds. Therefore, it is instructive to compare the structures of the HCN complexes of ionized heterocyclic aromatics such as pyridine and pyrimidine radical cations with the corresponding neutral complexes. In the neutral systems, e.g., pyridine $\cdot \cdot \mathrm{HCN}$, the existence of the aromatic conjugated system and the localized lone pair of electrons in pyridine provides the possibility of competitive interactions for various types of hydrogen bonds. For example, hydrogen bonding of the hydrogen atom in HCN to the $\pi$-system of pyridine prefers the T-shaped geometry while the interaction with the nitrogen lone pair of electrons leads to planar structures since the lone pair is located in the plane of the aromatic ring. However, in ionized aromatics only the $-\mathrm{CH}^{\delta+} \ldots \mathrm{NCH}$ type (or the $-\mathrm{NH}^{+} \ldots \mathrm{NCH}$ in protonated pyridine) of hydrogen bonds is observed since the T-shaped structures ((4-c), Fig. 3 and (1-a), (3-d), Fig. 7) do not involve $\mathrm{H}$-bonding as they represent ion-dipole interaction between the positively charged ring and the negative end of the dipole moment of HCN. It should be noted that the T-shaped hydrogen bonding of HCN to the $\pi$-system of the neutral aromatic becomes repulsive in ionized aromatics because of the positive charge on the ring and therefore, the HCN molecule must

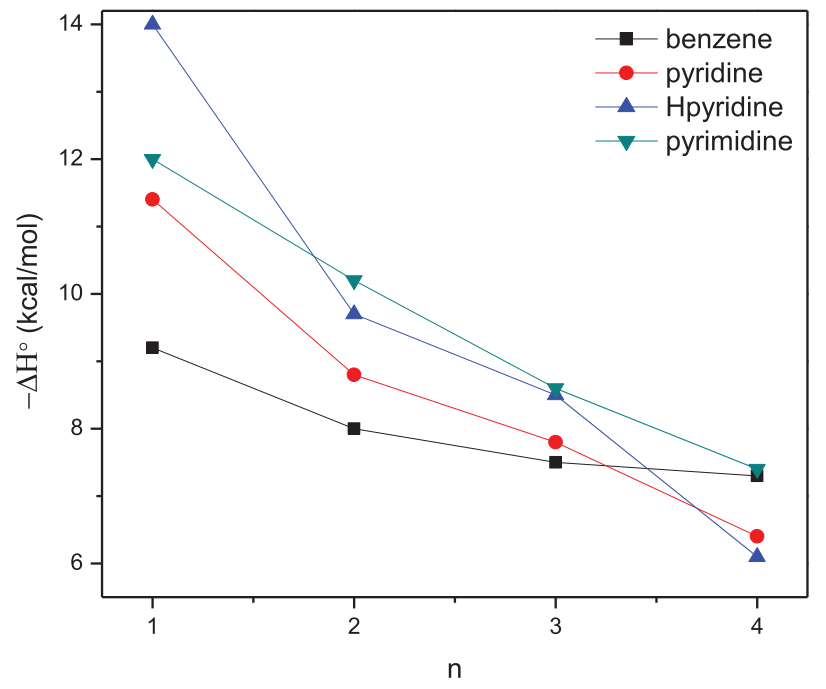

FIG. 9. Binding energy versus number of HCN molecules for the stepwise association with the benzene, pyridine and pyrimidine radical cations, and protonated pyridine. rotate $180^{\circ}$ to adopt a new T-shaped structure where the nitrogen atom of $\mathrm{HCN}$ is now facing the positively charged ring as in structures (1-a) and (3-d) in Fig. 7.

\section{E. Applications in astrochemistry}

Hydrogen cyanide is a significant component of interstellar clouds and solar nebulae. ${ }^{11-14}$ Aromatic molecules such as benzene, pyridine, pyrimidine, and polycyclic aromatic hydrocarbons (PAHs) could produce stable molecular ions under conditions of ionizing radiation. In these low-temperature environments, $\mathrm{HCN}$ can condense on the ions forming organic-doped ice grains. The protonation of the aromatic molecules and PAHs could result in significant binding of the polar space molecules such as $\mathrm{HCN}$ to the even-electron ions. The present systems model these processes, in particular, because the astrochemical condensation also involves stepwise addition of gas phase molecules.

\section{SUMMARY AND CONCLUSIONS}

Equilibrium thermochemical measurements using the ion mobility drift cell technique have been utilized to investigate the binding energies and entropy changes for the stepwise association of $\mathrm{HCN}$ molecules with the pyridine and pyrimidine radical cations forming the $\mathrm{C}_{5} \mathrm{H}_{5} \mathrm{~N}^{+\cdot} \cdot(\mathrm{HCN})_{\mathrm{n}}$ and $\mathrm{C}_{4} \mathrm{H}_{4} \mathrm{~N}_{2}+\cdot(\mathrm{HCN})_{n}$ clusters, respectively, with $\mathrm{n}=1-$ 4. For comparison, the binding of 1-4 $\mathrm{HCN}$ molecules to the protonated pyridine $\mathrm{C}_{5} \mathrm{H}_{5} \mathrm{NH}^{+}(\mathrm{HCN})_{n}$ has also been investigated. The binding energies of $\mathrm{HCN}$ to the pyridine and pyrimidine radical cations are nearly equal (11.4 and $12.0 \mathrm{kcal} / \mathrm{mol}$, respectively) but weaker than the HCN binding to the protonated pyridine $(14.0 \mathrm{kcal} / \mathrm{mol})$. The pyridine and pyrimidine radical cations form unconventional carbonbased ionic hydrogen bonds with $\mathrm{HCN}\left(\mathrm{CH}^{\delta+} \ldots \mathrm{NCH}\right)$. Protonated pyridine forms a stronger ionic hydrogen bond with $\mathrm{HCN}\left(\mathrm{NH}^{+} \ldots \mathrm{NCH}\right)$ which can be extended to a linear chain with the clustering of additional $\mathrm{HCN}$ molecules $\left(\mathrm{NH}^{+} \ldots \mathrm{NCH} \cdot \mathrm{NCH} \cdots \mathrm{NCH}\right)$ leading to a rapid decrease in the bond strength as the length of the chain increases. The lowest energy structures of the pyridine and pyrimidine radical cation clusters containing 3-4 HCN molecules show a strong tendency for the internal solvation of the radical cation by the HCN molecules where bifurcated structures involving multiple hydrogen bonding sites with the ring hydrogen atoms are formed. The unconventional $\mathrm{H}$-bonds $\left(\mathrm{CH}^{\delta+} \ldots \mathrm{NCH}\right)$ formed between the pyridine or the pyrimidine radical cations and $\mathrm{HCN}$ molecules are stronger (11-12 $\mathrm{kcal} / \mathrm{mol})$ than the similar $\left(\mathrm{CH}^{\delta+} \ldots \mathrm{NCH}\right)$ bonds formed between the benzene radical cation and $\mathrm{HCN}$ molecules $(9 \mathrm{kcal} / \mathrm{mol})$ indicating that the $\mathrm{CH}^{\delta+}$ centers in the pyridine and pyrimidine radical cations have more effective charges than in the benzene radical cation. HCN molecules can thus efficiently condense on the pyridine and pyrimidine cations in the low temperature space environments to form organic-doped ice grains which could affect the chemistry of complex organics in space. 


\section{ACKNOWLEDGMENTS}

We thank the National Science Foundation (CHE0911146) for the partial support of this work (A.M.H. and M.S.E.-S. at VCU). This work was funded by the Deanship of Scientific Research (DSR), King Abdulaziz University, Jeddah, Saudi Arabia under Grant No. 130-119-D1434 (S.G.A.). The authors, therefore, acknowledge with thanks DSR technical and financial support.

${ }^{1}$ G. A. Jeffrey, An Introduction to Hydrogen Bonding (Oxford University Press, Oxford, UK, 1997).

${ }^{2}$ C. L. Perrin and J. B. Nielson, "Strong hydrogen bonds in chemistry and biology," Annu. Rev. Phys. Chem. 48, 511-544 (1997).

${ }^{3}$ B. E. Conway, Ionic Hydration in Chemistry and Biophysics (Elsevier, Amsterdam, 1981).

${ }^{4}$ M. Meot-Ner, Chem. Rev. 112, PR22-103 (2012).

${ }^{5}$ J. Cerny and J. P. Hobza, Phys. Chem. Chem. Phys. 9, 5291 (2007).

${ }^{6}$ C. Menor-Salvan and M. R. Marin-Yaseli, Chem. Soc. Rev. 41, 5404-5415 (2012).

${ }^{7}$ Y. Ibrahim, E. Alsharaeh, K. Dias, M. Meot-Ner, and M. S. El-Shall, J. Am. Chem. Soc. 126, 12766-12767 (2004).

${ }^{8}$ Y. Ibrahim, E. Alsharaeh, M. Meot-Ner, M. S. El-Shall, and S. Scheiner, J. Am. Chem. Soc. 127, 7053-7064 (2005).

${ }^{9}$ R. Mabrouki, Y. Ibrahim, E. Xie, M. Meot-Ner, and M. S. El-Shall, J. Phys. Chem. A 110, 7334-7344 (2006).

${ }^{10}$ P. O. Momoh and M. S. El-Shall, Phys. Chem. Chem. Phys. 10, 4827-4834 (2008).
${ }^{11}$ C. N. Matthews and R. D. Minard, Faraday Discuss. 133, 393-401 (2006).

${ }^{12}$ K. A. Kvenvolden, J. G. Lawless, and C. E. Folsome, Scientific American 226, 38-46 (1972).

${ }^{13}$ C. N. Matthews and R. A. Ludicky, Adv. Space Res. 12, 21-32 (1992).

${ }^{14}$ M. J. Mumma et al., Science 310, 270-274 (2005).

${ }^{15}$ M. Meot-Ner, J. Am. Chem. Soc. 100, 4694-4699 (1978).

${ }^{16}$ M. Meot-Ner and C. V. Speller, J. Phys. Chem. 93, 3663-3666 (1989).

${ }^{17}$ A. M. Hamid, A. R. Soliman, and M. S. El-Shall, J. Phys. Chem. A 117, 1069-1078 (2013).

${ }^{18}$ I. K. Attah, A. M. Hamid, M. Meot-Ner, S. G. Aziz, A. O. Alyoubi, M. S. El-Shall, J. Phys. Chem. A 117, 10588-10579 (2013).

${ }^{19}$ A. M. Hamid, A. R. Soliman, and M. S. El-Shall, Chem. Phys. Lett. 543, 23-27 (2012).

${ }^{20}$ Y. Ibrahim, R. Mabrouki, M. Meot-Ner, and M. S. El-Shall, J. Phys. Chem. A 111, 1006-1014 (2007)

${ }^{21}$ A. M. Hamid, P. Sharma, R. Hilal, S. Elroby, S. G. Aziz, A. O. Alyoubi, and M. S. El-Shall, J. Chem. Phys. 139, 084304 (2013).

${ }^{22}$ M. J. Frisch, G. W. Trucks, H. B. Schlegel et al., GAUssian 09, Revision A.1, Gaussian, Inc., Wallingford, CT, 2009.

${ }^{23}$ See supplementary material at http://dx.doi.org/10.1063/1.4890372 for the arrival time distributions (ATDs) for the reactant and product ions to verify the attainment of equilibrium in the pyridine ${ }^{+} \cdot(\mathrm{HCN})_{n}$ (Figure S1) and pyrimidine $^{+\cdot}(\mathrm{HCN})_{\mathrm{n}}$ clusters (Figure $\mathrm{S} 3$ ), and calculated atomic charges and geometries of pyridine and pyrimidine radical cations, and protonated pyridine (Figure S2).

${ }^{24}$ NIST Chemistry WebBook, NIST Standard Reference Database Number 69, edited by P. J. Linstrom and W. G. Mallard (National Institute of Standards and Technology, Gaithersburg, MD, (retrieved July 16, 2014)), p. 20899, see http://webbook.nist.gov. 